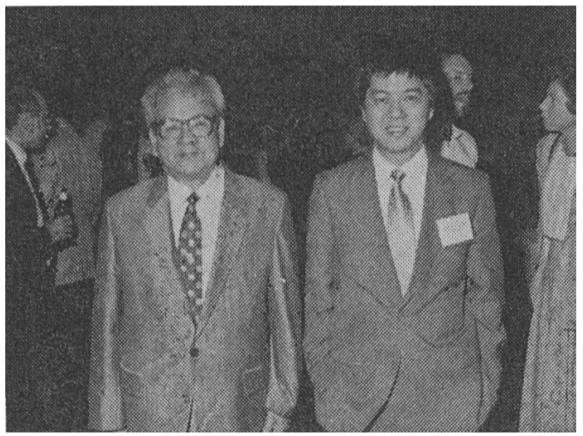

Tai-Shuenn Yang (r.) pictured here with his father, received the Leo Strauss Award for the best dissertation in the field of political philosophy.

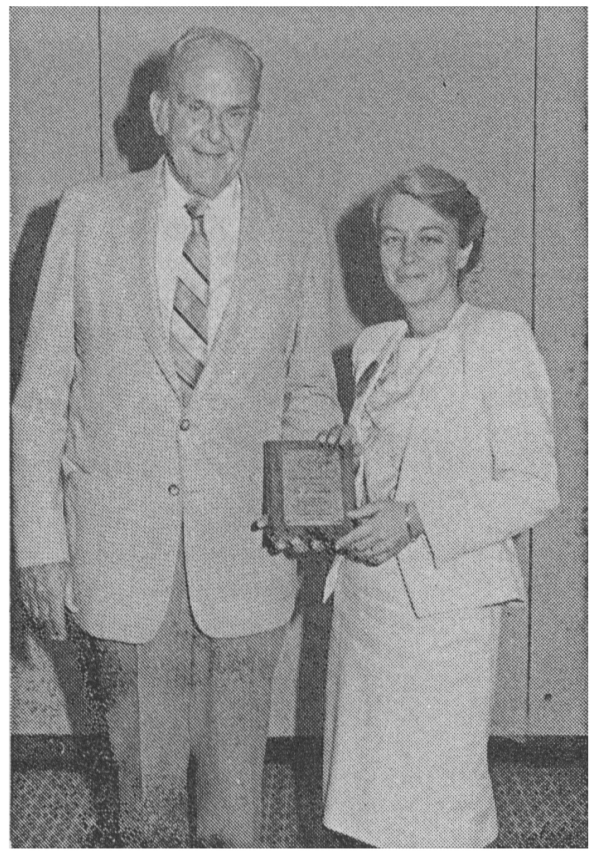

Trudi Miller presents the Policy Studies Section's Donald Campbell Award to Donald Campbell.

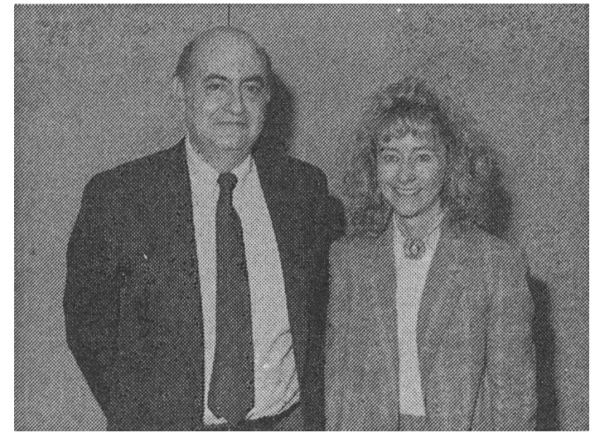

Joseph Cooper and Cheryl Young, recipients of the Legislative Studies Section's CQ Award.

The Leonard D. White Award for the field of public administration was awarded to Roy $T$. Meyers of the Congressional Budget Office for his dissertation, Microbudgetary Strategies and Outcomes, submitted by the University of Michigan; dissertation chair, John Kingdon.

Editor's Note: For the full text of citations, see the Gazette in this issue of PS.

\section{APSA Sections Distribute Awards at 1989 Annual Meeting}

The Policy Studies Section presented the Donald Campbell Award for an outstanding methodological innovator in public policy to Donald Campbell of Lehigh University. Trudi Miller, University of Minnesota, received the Policy Studies Organization Paper Award for the best policy studies paper presented at the 1988 Annual Meeting; her paper was entitled, "Designing Social Structures: A Scientific Perspective." The Section's Hubert $H$. Humphrey Award for outstanding scholarship contributing to the understanding public policy practitioner was posthumously awarded by Dale Rogers Marshall of Wellesley College to Charles Levine. Martha Derthick of the University of Virginia was presented with 


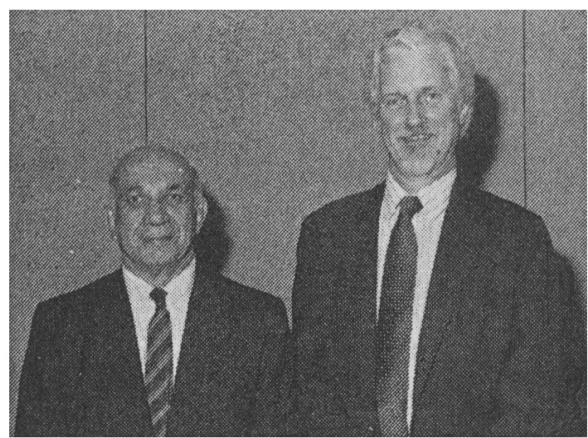

ALLAN KORNBERG and ROBERT SALISBURY

the Section's Harold D. Lasswell Award for outstanding scholarly contribution to the understanding of the substance or process of public policy. The Section presented the Theodore Lowi Award for the best article in Policy Studies Journal in 1988 to Jeffrey Stonecash of Syracuse University for his article entitled, "Inter-party Competition, Political Dialogue, and Public Policy: A Critical Review." The Jeffrey Pressman Award for the best article in the Policy Studies Review in 1988 was presented to William N. Dunn of the University of Pittsburgh for his article, "Methods of the Second Type: Coping with the Wilderness of Conventional Policy Analysis." The PSO Book Prize was awarded to David T. Ellwood of Harvard University for his book, Poor Support (Basic Books).

Allan Kornberg of Duke University received the Political Organizations and Parties' Samuel Eldersveld Award recognizing a lifetime of distinguished scholarly and professional service to the field. The POPS Section's Leon Epstein Award for a book that has made a distinguished contribution to the field went to Anthony Downs of the Brookings Institution for his book, An Economic Theory of Democracy (Harper \& Row). The award for the best article of unusual importance or significance in the field was received by Robert Salisbury of Washington University, St. Louis, for his article, "An Exchange Theory of Interest Groups," published in the Midwest journal of Political Science (February 1989).

The Presidency Research Section recognized Erwin Hargrove of Vanderbilt Uni-

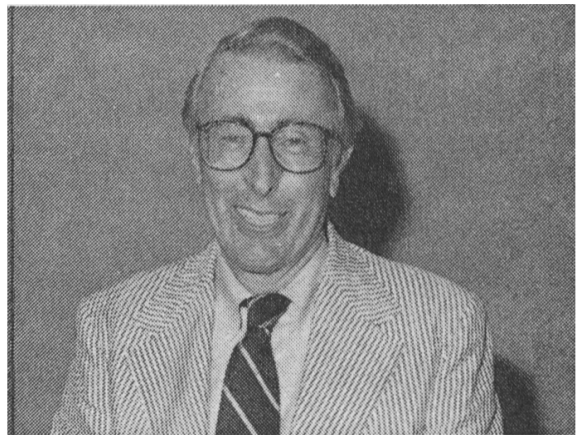

ERWIN HARGROVE

versity with its Richard E. Neustadt Award for the best book published in 1988 contributing to research and scholarship in the field of the American presidency. Hargrove was honored for his book, jimmy Carter as President, published by Louisiana State University Press.

James Doig of Princeton University was presented with the Public Administration

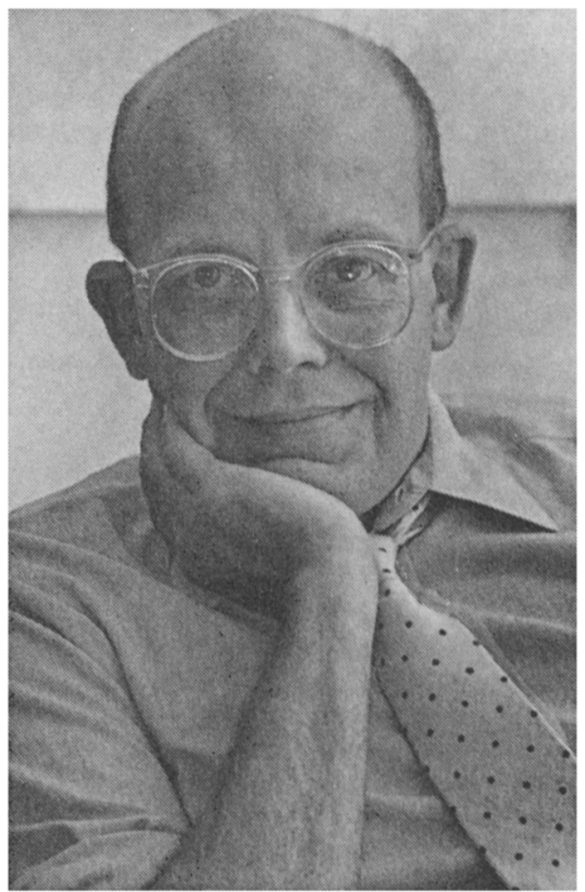

DOUGLAS RAE 


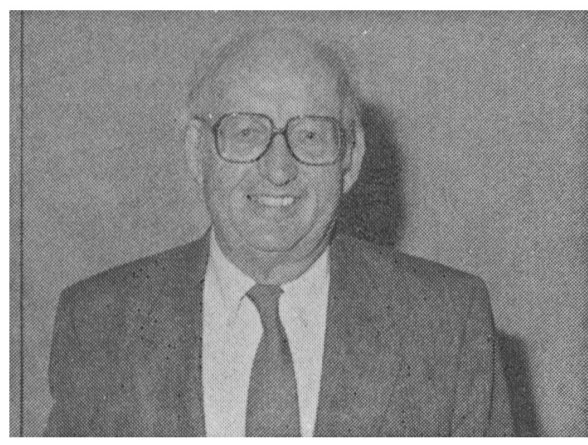

ROBERT C. WOOD

Section's Herbert Kaufman Award for the best paper in public administration presented at the previous year's Annual Meeting. Doig was recognized for his 1988 paper, "Entrepreneurship in Government."

The first George Hallett Prize of the Representation and Electoral Systems Section was presented by Bernard Grofman, of the University of California, Irvine, to Douglas Rae of Yale University. The Hallett Prize for a book published at least ten years ago that has made a lasting impression in the understanding of representation and electoral systems recognized Rae's The Political Consequences of Electoral Laws (Yale University Press, 1967; 2nd revised edition, (97I).

\section{Urban Politics Section Awards, 1989}

The APSA Organized Section on Urban Politics and Policy presented the following awards at the 1989 Annual Meeting in Atlanta, Georgia:

Robet C. Wood, Henry Luce Professor of Democratic Institutions and the Social Order, Wesleyan University, the 1989 Career Achievement Award for distinguished scholarship in the field of urban politics.

Charles V. Hamilton, Wallace S. Sayre Professor of Government, Columbia University, Special Award for scholarly con- tributions to understanding the racial problems and politics in American cities.

Steven P. Erie, University of California, San Diego, Best Book in Urban Politics in 1988, for his book Rainbow's End: Irish Americans and the Dilemmas of Urban Mochine Politics, 1840-1985. Erie's book also was awarded the 1989 Robert Park Award given by the American Sociological Association.

Lawrence A. Cremin, Columbia University, 1988 Special Citation for his book American Education, The Metropolitan Experience, 1876-1980.

James $C$. Clingermayer, Texas A\&M University, for the best dissertation completed in 1988. His dissertation, submitted by Washington University, St. Louis, is entitled, "The Political Economy of Municipal Zoning." The Section's dissertation award is sponsored by the Urban Affairs Quarterly and the journal of Urban Affairs.

\section{Richard F. Fenno, Jr. Prize for 1989 Announced; Award Committee for 1990 Set}

The Legislative Studies Section of the American Political Science Association announced the 1989 winner of the Richard F. Fenno, Jr. Prize at the LSS Awards Ceremony held in Atlanta at the APSA Annual Meeting. The Fenno Prize honors the outstanding book published during the preceding year in legislative studies, including American, non-American, cross-national, and sub-national works.

The 1989 Fenno Prize was conferred upon David Brady of Stanford University for his book Critical Elections and Congressional Policy-Making, published in 1988 by Stanford University Press. The LSS Committee that decided upon the Fenno Prize was chaired by Morris Fiorina of Harvard University. Other members of the Fenno Committee were Gerhard Loewenberg of 